\title{
Influence of prenatal class to the practice of P4K (Birth Planning and Prevention of Birth Complication)
}

\author{
Robitha Faiza', Hari Basuki Notobroto², Bambang Trijanto ${ }^{3}$, Oedojo Soedirham ${ }^{4}$, \\ Ah. Yusuf ${ }^{5}$, Kusuma Halim ${ }^{5}$
}

'Public Health Master Program, Faculty of Public Health, Universitas Airlangga, Surabaya, ${ }^{2}$ Biostatistic and Epidemiology Department, Faculty of Public Health, Universitas Airlangga, Surabaya, ${ }^{3}$ Department of Obstetrics and Gynecology, Dr Soetomo Hospital,, ${ }^{4}$ Behavior Department, Faculty of Public Health, Universitas Airlangga, Surabaya, ${ }^{5}$ Adi Husada Undaan Hospital Surabaya

\begin{abstract}
ABSTRAK
Tujuan: Untuk mengetahui pengaruh kelas ibu hamil terhadap Praktik P4K.

Bahan dan Metode: Penelitian ini menggunakan pendekatan cross sectional. Sample yang digunakan dalam penelitian ini 30 responden dengan teknik sampling yaitu simple random sampling. Uji analisis yang digunakan wilcoxon sign rank test.

Hasil: Terdapat pengaruh kelas ibu hamil terhadap praktik $\mathrm{P} 4 \mathrm{~K}$ $(\mathrm{p}=0,0000)$

Simpulan: Kelas ibu hamil mempunyai pengaruh terhadap praktik $\mathrm{P} 4 \mathrm{~K}$
\end{abstract}

Kata Kunci: kelas ibu hamil, Praktik P4K (Perencanaan

Persalinan dan Pencegahan Komplikasi)

\begin{abstract}
Objective: This study aimed to analyze the influence of prenatal class to the practice of P4K (Birth Planning And Prevention Of Birth Complication).

Materials and Methods: This study applied analytical survey with cross sectional approach. The number of samples taken was as many as 30 mothers, using simple random sampling. Analysis of data was carried out using ordinal wilcoxon sign rank test. Datas were obtained from interviews and questionnaire.

Result: The influence of prenatal class to practice of P4K (Birth Planning and Prevention of Birth Complication) $(\mathrm{p}=0,0000)$. Conclusion: Prental class can influence to practic of $\mathrm{P} 4 \mathrm{~K}$.
\end{abstract}

Keyword: Prenatal Class, practice of P4K

Correspondence: Robitha Faiza, Public Health Master Program Faculty of Public Health Airlangga University Surabaya, phone: 082337590448; email: robithafaiza@gmail.com

\section{INTRODUCTION}

One of the government's efforts to realize integrated and good quality antenatal is to empower pregnant women with classes for pregnant women. Prenatal classes' activities facilitate pregnant women about P4K (Birth Planning and Prevention of Complications). Prenatal class is a means to learn together about the health of the pregnant women, in face-to-face form in a group. The prenatal class' objectives are to improve the knowledge and skills of mothers about prenatal care so that the mother and fetus are healthy (definition of pregnancy, signs of pregnancy, the complaints during pregnancy, physical and emotional changes in pregnancy, maintaining a healthy mother and a healthy and intel-ligent fetus, things that need to be avoided during preg-nancy, the myth/taboo, and preparation for childbirth), safe, comfortable labor, healthy mothers and babies, disease and complications of pregnancy preven-tion, for healthy mother and baby, newborns care to reach optimal growth and development.

Indicators of output expected from Prenatal Class program is an increase in coverages of $\mathrm{K} 1, \mathrm{~K} 4$, precent-age of mother or family with birth planning by health personnel, percentage of postpartum visits coverage, percentage of neonatal visits coverage.

Based on the results of a research by Tinah, there was a significant influence among pregnant women implementation class program on knowledge and attitudes of pregnant women in the early detection of high risk. ${ }^{1}$ Based on research, interventions for pregnant mother in the form of classes were able to improve knowledge and attitudes about pregnancy and childbirth in pregnant women. ${ }^{2}$

Prenatal class program in Bondowoso has been socialized since 2006 and has been implemented since 2007. Information obtained from the Health Office of Bondowoso (2014) ${ }^{3}$, PHC Grujukan Bondowoso consists of 19 villages and has prenatal class program which is active in 11 villages. The majority of the residents are farmers and traders so that the mother has a time that allows them to attend classes despite the implementation of prenatal classes are held during working hours (daytime). The facilitators are midwife coordinators or midwives who have followed the facilitators training so that the prenatal class in the working area of the clinic can run well. 
Planning for childbirth and prevention of complications become one determinant of success in the management of obstetric maternal and neonatal emergency that can reduce Maternal and Infant Mortality Rate. Birth planning and prevention of complications includes birth due date planning, birth attendants, labor location, labor companion, transport for labor, potential blood donors. Integrated plan and prevention of the complications of childbirth will cause faster handling of emergencies in neonatal and maternal complications during pregnancy, childbirth, and postpartum.

Maternal and infant deaths become an important issue on the agenda to achieve the optimal health level. Target Maternal Mortality for SDG's 2030 is to improve the quality of maternal welfare with indicators of maternal mortality rate (MMR) at 70 per hundred thousand live births ${ }^{4}$ MMR describes the number of women who die of a cause of death associated with pregnancy disorders and treatments (excluding accidents or incidental cases) during pregnancy, childbirth and the postpartum period (42 days after birth) regardless of the duration of pregnancy per 100,000 live births 5 .

The maternal mortality rate in 2015 in Indonesia was 93 per 100,000 live births. The achievement of the maternal mortality rate (MMR) in East Java is likely to increase in the last 5 years, ranging from 7-11 points with the data from the districts/city reports on maternal mortality (LKI) ${ }^{6}$. Achievement of MMR in east Java in 2012 reached 97.43 per 100,000 livebirths. It showed the state of MMR in East Java was still four points below the average maternal mortality in Indonesia ${ }^{7}$

The maternal mortality rate is still relatively high in Bondowoso. Bondowoso is one of the districts in East Java who have MMR above the average achievements of AKI in East Java that is equal to 109.5 per 100,000 live births (Health Profile of East Java, Ministry of Health 2012). IMR, in Bondowoso was still far from East Java performance which is 53.93 per 1,000 live births. The number of maternal deaths in Bondowoso in 2014 was 20 deaths. In January 2016 there were 5 maternal deaths in one month. ${ }^{8}$

Grujukan PHC, is one of the health centers in Bondowoso, which contributes to Maternal and Neonatal Mortality. In 2014, at Grujukan PHC 3 maternal deaths occured, it was caused by ecclampsia, bleeding, and heart disease. The death occurred in primary health facilities. It could have been prevented with by planning deliveries and prevention of complications when the danger signs of pregnancy or risk pregnancy were found. Mothers who have good birth plans and prevention of complications have a good preparation and quick handling of decision-making when the cases of emergency were discovered. Thus, service of emergency cases can be dealt immediately in adequate health facilities.

The cause of maternal death can be classified into a direct cause and indirect causes. The direct causes, usually related to the health condition of mothers since pregnancy, childbirth and postpartum, indirect causes are more associated with social, economic, geographic, and community behavior, including whether there is a gender inequality. The direct causes of maternal deaths are caused by bleeding $28.0 \%, 24 \%$ ecclampsia, $11.0 \%$ infections, $8 \%$ postpartum complications, $5 \%$ obstetric trauma, 55 protracted partus, 55 protracted/prolonged partus, $5 \%$ abortion, $5 \%$ obstetric embolism ${ }^{9}$.

Indirect factors that cause infant mortality rate, there are also indirect causes that added the risk of maternal mortality which is related to the mother's health is "4 toos": Too young, too often, too old to get pregnant in the first time, too close (weak, severe anemia). And "3 lates": Decision makers in the family are too late, too late to reach emergency obstetric facilities and late to obtain help.

Direct or indirect factors could be prevented with good birth planning and prevention of complications. Planning for childbirth and prevention of complications according to the risk of mother to prevent maternal and neonatal emergencies. Most of the maternal mortalities are caused by high-risk pregnancy. This high-risk pregnancy can be overcome with good birth planning so that the referral is planned and good handling in emergency cases. This emergency cases if they are not treated quickly and appropriately will result in the death of the mother or fetus. Planning for deliveries will either accelerate treatment when obstetric and neonatal emergencies are discovered.

Planning of childbirth and prevention of complications can plan the delivery in accordance with the mother's condition. Emergency cases can be dealt with quickly in accordance with the conditions for the mother because it has been planned in accordance with the conditions of the mother's pregnancy. Birth planning plan the delivery according to the conditions of the mother to make a safe and healthy birth.

Empowerment of pregnant women with prenatal class can improve the practice of $\mathrm{P} 4 \mathrm{~K}$ so the maternal mortality rate can be decreased. In this case a research entitled " Influence of Prenatal Class with Practice of P4K (Birth Planning And Prevention Of Birth Complication)" is needed. 


\section{MATERIALS AND METHODS}

This research was an analytic observational study, the researchers simply did observations only and did not provide treatment or intervention at all. The design was cross sectional. Because it was done through observation of the study subjects once in some times or a given period. The researcher only made observations on prenatal class, without intervention on the variable to be studied, which uses the group that was measu-red before being given a prenatal class and after a class.

To know the influence of prenatal class in practice of $\mathrm{P} 4 \mathrm{~K}$. The location of this study was conducted in Grujukan PHC. The study was conducted starting in May 2016 to June 2016. The population in this study were all pregnant women in the region of Grujukan PHC in 2016, which were 74 pregnant women. Sample used in this study were 30 pregnant women.

The independent variable in this study was a class of pregnant women, while the dependent variable in this study is $\mathrm{P} 4 \mathrm{~K}$ practice.

The research datas that were obtained from the field is still the raw datas, they were then processed and calculated using a frequency distribution table. For analysis of the data, this study used the Wilcoxon signed rank test to see the influence of the independent variables (prenatal class) to the dependent varia-ble ( $\mathrm{P} 4 \mathrm{~K}$ practice).

\section{RESULT AND DISCUSSION}

Baseline characteristics of prenatal class' participants are presented in Table 1 . Table 2 presents the content of prenatal class. In Table 1, it was found that the most respondents were not in the risk age $(76.4 \%)$, did not work $(96.7 \%)$, had basic education $(73.3 \%)$, their incomes were below the regional minimum wage $(88.2 \%)$, primiparity $(90 \%)$, and were in the second trimester (70\%). In Table 2, the majority of the respondents said that thematerials taught by prenatal class' facilitators was quite clear (60\%).

Influence of the prenatal class to the practice of $\mathrm{P} 4 \mathrm{~K}$ that was conducted on 30 respondents in this research is in Table 3. From Table 3 it can be concluded that the average knowledge of the mother before entering the class of pregnant women was 72.47 with a standard deviation of 7.61. And the maximum value obtained by mother is 88 , while the minimum value is 52. Practice average of the mother after joining the prenatal class was 84.27 with a standard deviation of 7.21. And the maximum value is 94 , while the minimum value is 72 . There was an influence of prenatal class to the practice of $\mathrm{P} 4 \mathrm{~K}$ with $\mathrm{p} 0.000$ less than 0.05 .

Table 1. Baseline characteristics of prenatal class' participants.

\begin{tabular}{ccc}
\hline Variables & \multicolumn{2}{c}{ Prenatal class' participant } \\
\hline Age $\quad$ N $\quad 30$ & $\%$ \\
Risk (<20 years) & 7 & 23.3 \\
not at risk & 23 & 76.4 \\
Risk (> 35 years) & - & - \\
Work & & \\
Work & 1 & 3.3 \\
Does not work & 29 & 96.7 \\
Education & & \\
not Attend & 2 & 6.7 \\
basic education & 22 & 73.3 \\
Middle education & 6 & 20 \\
higher education & - & - \\
Income & & \\
<IDR. 1.417 million & 26 & 88.2 \\
$\geq$ Rp. 1.417 million & 4 & 11.8 \\
parity $\quad$ & \\
primiparas & 27 & 90 \\
multiparas & 3 & 10 \\
Grandemultipara & - & - \\
Gestational age & & 70 \\
trimester 2 & 21 & 30 \\
trimester 3 & 9 & \\
\hline & &
\end{tabular}

Table 2. Clarity of the subjects taught by class' facilitator

\begin{tabular}{lcc}
\hline & \multicolumn{2}{c}{ Amount } \\
\cline { 2 - 3 } Clarity of the subjects & $\mathrm{N}$ & $\%$ \\
\hline Very clear & 12 & 40 \\
Quite clear & 18 & 60 \\
Amount & 30 & 100 \\
\hline
\end{tabular}

The results showed there was an influence of prenatal class to the $\mathrm{P} 4 \mathrm{~K}$ practice $(\mathrm{p}=0.000)$. Statistical analysis showed differences in the practice of $\mathrm{P} 4 \mathrm{~K}$, before and after prenatal class was given. The average of the practice increased in the birth planning and prevention of complications before entering the prenatal class and after taking the class. Before participating the prenatal class the average practice of mothers in birth planning and prevention of complications was 72.47 , after the mother took the prenatal class it became 84.27. The standard deviation prior to prenatal class participation was 7.61, after tooking the prenatal class the standard deviation became 7.21. Meanwhile after taking part in the prenatal class, mother who had minimum mark had the mark increase, before entering the prenatal class the minimum mark was 52, after taking part in a prenatal class the mark of the minimum practice was 72 . The prenatal class have been facilitated by efforts to support pregnant women in the achievement of $\mathrm{P} 4 \mathrm{~K}$. On the first day of prenatal class material about $\mathrm{P} 4 \mathrm{~K}$ were given. 
Table 3. Influence of prenatal class to the practice of $\mathrm{P} 4 \mathrm{~K}$

\begin{tabular}{lccccccc}
\hline Variables & $\mathrm{N}$ & Mean & Median & SD & Min. & Max. & $\begin{array}{c}\text { Asymp.Sig. } \\
\text { (2-tailed) }\end{array}$ \\
\hline Before & 30 & 72.47 & 67,50 & 7.61 & 52.00 & 88.00 & .000 \\
After & 30 & 84.27 & 85.50 & $7: 21$ & 72.00 & 94.00 & .00 \\
\hline
\end{tabular}

Giving the material as an effort to improve mothers' knowledge of $\mathrm{P} 4 \mathrm{~K}$. The materials on this $\mathrm{P} 4 \mathrm{~K}$, consisted of due-date of labor, labor attendant, birth place, birth companion, transport-tation, potential blood donors, the need for labor, labor savings, and post-labor contraception. The materials were taught through informal discussion, questions and answers, and experiences sharing with partici-pants. Facilitators also used the media Maternal and Child Health book to deliver the content of $\mathrm{P} 4 \mathrm{~K}$. This made the mother became active in the classroom activities for pregnant women. They were also asked to write their birth planning at P4K book, and asked to fill $\mathrm{P} 4 \mathrm{~K}$ sticker and paste it in front of their house.

Communication used in the delivery of the material by the facilitator was informative, persuasive, and conversive communication. The facilitator presented the material with a notice to the class participants verbally with lectures, through question and answer, and discussion. As well as writing, using tools, such as prenatal class flip chart.

Information provided includes information about $\mathrm{P} 4 \mathrm{~K}$ that consist of due-date of labor, labor attendant, birth place, birth companion, potential blood donors, the need for labor including birth and newborn equipments, labor savings, post-labor contraception and sticking the P4K sticker. Every expectant mother and family should know the approximate date of labor. By knowing the due date of birth mother was ready for delivery and accompanied by a husband or family. Labor can occur 2 weeks before or after the due date. Birth attendant should also be known early. The birth attendant adjusted mother's pregnancy. Mothers who had a risk in pregnancy need to plan the deliveries in adequate health facilities to anticipate their obstetric emergency. The facilitator also described several categories of mothers who fall into high risk. Thus, the mother can find out what condition of pregnancy she is now. Funds for maternity also need to be prepared since early pregnancies. Families should also prepare transportation or vehicles to bring mothers who give birth to a health facility. If the mother does not have a vehicle to achieve maternal health facilities she can request public assistance for ambulance belonging to the resident. In this prenatal class an agreement of several vehicles that could be used for an ambulance was obtained with community approach, with the results of the village, such as cars in the village office and car of the village's chief. The mothers also needed to set up a blood donor, anytime it is needed a quick transfusion can be performed. Post-labor needs to mothers and newborns also need to be prepared. Health facilities do not always provide maternal and newborn babies supplies, so that mothers and families should prepare the equipment themselves. Providing this information can enhance the coverage and quality of maternal health care, and mothers in labor. Puerperal women and newborns through the increase of mothers and families' active role in planning for safe delivery and preparation to face complications and danger signs of obstetric and newborn so that the mother could give birth a healthy baby.

The facilitator used persuasive communication. Facilitators delivered the material to persuade the mother so that the mother planned her labor, and the prenatal class' participants with their self-consciousness and voluntarily accept and implement the contents of the message that is planning the childbirth and preventing the complications. Persuasive communication emphasizes more on behavioral changes; it stresses more to the direct oral communication and expects a response right away. The facilitator also involved the family, the companion of prenatal class to help mothers decide. Beside the facility, the support factor from the other party was also needed to make a decision. In a class of pregnant women, family arrival to accompany the mother was expected in a class of pregnant women. Family served as mothers' supporter in receiving the material and as the decision makers. Companion in prenatal class was expected to help the mother to plan the childbirth and prevent complications. Decisions in the place of delivery, birth attendants, and transport can be discussed with the family when the mother was accompanied by the family in the prenatal class. Family was also as the support factors that influence the success of labor planning and prevention of complications.

The facilitator presented the material with conversive communication. The process of teaching the material by the facilitator was forced, containing punishment and if the message was not implemented, the participant would bear the risks and consequences. Lack of childbirth planning and prevention of complications in pregnant women would have the impact on pregnant women and fetus. Through the Program of Birth Planning and Prevention of Complications $(\mathrm{P} 4 \mathrm{~K})$ with a sticker that is 
sticked to the houses of pregnant women, then every pregnant woman will be registered, recorded and monitored appropriately. With the data in stickers, husband, family, cadres, along with the midwife in the village can intensively monitor the situation and development in the health of pregnant women. Beside that, pregnant women will receive appropriate care standards during antenatal, delivery and post-partum so that the process of childbirth to puerperal phase including the referral can be run safely. Attachment of P4K stickers in every home of pregnant women means that pregnant women are registered, recorded and the condition is reported by midwives involving the active elements of society such as cadres, quack and community leaders. Communities around the mother's residence know that there are pregnant women and at any time when in need, the community is ready to assist. Thus, pregnant women with complications are not too late to get proper and fast treatment.

Prenatal class is also facilitated by blood tests for pregnant women and families. Blood tests for pregnant women, carried out on the second day after the end of a material teaching in class. Many pregnant women do not know their blood types and have not checked the blood type. Blood type is very important to know the compatibility between blood donors and recipients of blood. Blood type is not only as a complement to the identity cards of pregnant women. This can prevent the risk of complications during pregnancy, childbirth, or postpartum, helping pregnant women in an emergency and taking important decisions. On the third day of the prenatal class a blood test to determine family blood type is done and as the blood bank of the village. In a blood transfusion, a match between a blood donor (giver) and recipient (receiver) is very important. Blood donor and recipient must be compatible based on $\mathrm{ABO}$ and Rhesus factor systems.

\section{CONCLUSION}

Prenatal class influences the practice of P4K (Birth Planning and Prevention of Complications)

\section{REFERENCES}

1. Kementrian Kesehatan RI. Pedoman Antenatal Terpadu. Direktorat Jendral Bina Kesehatan Ibu dan Anak Kementrian Kesehatan Republik Indonesia. Jakarta. 2011.

2. Kementrian Kesehatan RI. Pedoman Pelaksanaan Kelas Ibu Hamil. Direktorat Jendral Bina Kesehatan Ibu dan Anak Kementrian Kesehatan Republik Indonesia. Jakarta. 2012.
3. Depkes RI. Pedoman Umum Manajemen Kelas Ibu Hamil. Jakarta. Depkes RI. 2012.

4. Depkes RI. Profil Kesehatan Indonesia 2013. Retrieved from: http://www.depkes.go.id/resources/ download/pusdatin/ profil-kesehatan indonesia/ profil- kesehatan- indonesia- 2013.pdf. 2013. Diakses 15 October 2014.

5. Hidayat A. Riset Keperawatan dan Tehnik Penulisan Ilmiah. Jakarta: EGC; 2009.

6. Nursalam P. Pendekatan Praktis Metodologi Riset Keperawatan. Jakarta: Infomedia; 2011.

7. Hidayat A. Metode Penelitian Keperawatan dan Teknik Analisa Data. Jakarta: Salemba Medika; 2009.

8. Christiana A. Pengaruh Keikutsertaan Kelas Ibu Hamil Terhadap Kejadian Komplikasi Persalinan di Wilayah Kerja Puskesmas Bumiaji kota Batu. Tesis. Universitas Airlangga. 2015.

9. Dyah P. Pengaruh Kelas Ibu Hamil terhadap Pengetahuan dan Sikap Ibu dalam Kehamilan dan Persalinan di Wilayah Puskesmas Gurah Kabupaten Kediri, Surakarta. Tesis. Universitas Sebelas Maret. http://pasca.uns.ac.id/?p=2812. 2012. Diakses 12 Maret 2016.

10. Handriani B. Pengaruh Proses Rujukan Emergency Obstetric Terhadap Kematian Ibu di RSUD Sidoarjo. Tesis. Universitas Airlangga. Surabaya. 2015.

11. Kementrian Kesehatan RI. Pelayanan Kesehatan Ibu di Fasilitas Kesehatan Dasar dan Rujukan. Jakarta: Kementrian Kesehatan; 2013.

12. Kementrian Kesehatan RI. Pedoman Penyelengaraan Puskesmas Mampu Poned. Jakarta. 2013.

13. Pathonah S. Analisis Social Capital dalam Pencapaian Program Perencanaan Persalinan dan Pencegahan Komplikasi (P4K). Tesis. Universitas Airlangga. Surabaya. 2010.

14. Maulana DJ. Promosi Kesehatan. Jakarta: Penerbit EGC; 2010.

15. Notoatmodjo S. Promosi Kesehatan Teori dan Aplikasi. Jakarta: Rineka Cipta; 2010.

16. Notoatmojo S. Metodologi Penelitian. Jakarta: Rineka Cipta; 2010.

17. Notoatmodjo S. Pendidikan dan Perilaku Kesehatan. Jakarta: Rineka Cipta; 2005.

18. Nursalam. Konsep dan Penarapan Metodologi Penelitian Ilmu Keperawatan. Jakarta: Salemba Medika; 2008.

19. Sarwono P. Ilmu Kebidanan. Jakarta: EGC; 2013.

20. Widya. Pengaruh Penyuluhan Kelas Prenatal Plus Terhadap Pengetahuan Dan Sikap Ibu Hamil Di Wilayah Kerja Puskesmas Mamboro Kecamatan Palu Utara. Tesis. Universitas Hasanudin. Diakses dari:http://pasca.unhas.ac.id/jurnal/files/533c77187 d305944329066432e78534a.pdf. 2012. Diakses 2 Maret 2016. 
Majalah Obstetri \& Ginekologi, Vol. 24 No. 3 September - December 2016 : 94 - 99

21. Rochjati P. Skrinning Antenatal Pada Ibu hamil, Pengenalan Faktor Risiko Deteksi Dini Ibu Hamil
Risiko Tinggi. Edisi ke-2. Surabaya: Airlangga University Perss; 2011. 